\title{
Signals, Systems, and Environment in Industrial Food Production
}

\author{
E. Paul Durrenberger and Kendall M. Thu
}

\section{Introduction}

It seems that wherever people start large scale swine production facilities, the neighbors begin to complain. Some are worried about odor and water; others about the fate of farms and farmers who operate on smaller scales of production; still others about the possibilities of the demise of rural communities heralded by Goldschmidt in his studies of industrial agriculture in California (Goldschmidt 1978, Labao 1993).

Across Iowa and other pork producing states there are highly publicized debates, hearings, conferences, and trials concerning air and water quality and odor as well as social and economic issues related to industrial scale swine production. Neighbors become enemies because of law suits and disputes over permits. Rural residents organize to oppose industrial swine operations. On the one hand are visions of self contained, perpetually sustainable family farms representing all that is best in the ideals of the yeoman farmer of Jeffersonian America and the rural prosperity that accompanies widespread small owneroperated farms. On the other are conceptions of highly efficient industrial production, economies of scale, and the prosperity that industry and attendant jobs bring.

In between these two highly politicized positions are a number of people who worry about environmental quality, the costs of monitoring industrial operations, whether small farmers can afford to meet stringent environmental rules, the fate of small farmers in a market dominated by industrial giants, the sustainability of industrial operations, how swine production is related to the meat packing industry, and the future of rural communities.

Our purpose is to begin to understand the status of a variety of signals within the channels of a large and complex state system which also includes channels that promote large scale swine facilities. Definitions of states (e.g. Fried 1967) emphasize that they are based on the radical distinction of interests among their component classes. The sense in which the "society" as a whole adapts is thus unclear because different classes have different interests.

Marx located the dynamic of capitalist states in the tensions between those classes that own the means of production and those whose product they appropriate by a wage system. He suggested that when those whose production was appropriated came to understand the operation of their political-economy they would re-organize it to their own advantage. A puzzle was posed when the spread of education and voting privileges throughout nations and classes did not result in such re-organization by electoral means.

Gramsci's solution was that the ruling class successfully controls peoples' thought through religion, schools, and media so people could never accurately understand the conditions of their existence. After the literary historian Williams (e.g. 1977) developed this notion, the term "hegemony"--how states control everyday thought processes-achieved some currency among anthropologists. 
When James Scott $(1985,1991)$ observed in daily life incontrovertible evidence that no one is fooled by the images of the 'public transcript' that contradict experience, he concluded that ruling class control of ideology is far from complete. He found a plethora of acts of resistance based on very clear comprehension of socio-political realities. The ruling classes maintain control, he argued, finally, because they control the use of force. "Resistance" became a popular term among anthropologists.

Other anthropologists have sidestepped the issue of institutional or cultural determination and, adhering to the assumptions of methodological individualism, have devoted much effort to understanding individual decisions (Barlett 1989, Bennett 1982, Gladwin 1980, Gladwin and Butler 1984, Gladwin and Murtaugh 1980, Gladwin and Truman 1989, Gladwin and Zulauf 1989, Mathews 1987). Rather than assuming that institutions determine behavior or thought, they assume that systemic change results from individual decisions and actions. However, farmers' decisions are so heavily constrained and conditioned by the policies that create the conditions within they must operate and make decisions that their decisions are some of the least significant parts of the process. The significant questions are about the constraints, not the decisions.

Individual farmer decisions do not create the systems in which they operate. The multiplicity of interests makes adaptation an inappropriate concept for understanding states. Force is rarely exercised because it is expensive and alienating. And we assume that the ruled are no less clever than the ruling. We argue that we can understand such processes as the industrialization of swine production and its discontents by considering states as information processing systems (Flannery 1972, Johnson 1978, Johnson 1982, Kus 1981, Reynolds 1984, van der Leeuw 1981, Wright 1986) and tracing the role of cultural signals to pinpoint the loci of their impact on policy.

Rather than relying on a single dominant concept such as adaptation, hegemony, individual decisions, class struggle, or resistance, we suggest that this approach allows us to understand just how members of different classes contest the control of resources, just how people resist, and just how dominant interests exercise their dominance. By showing how different interests inform policy decisions and implementation, we can show how complex states are parts of more complex ecological relationships.

State policy shapes the limits, forms, and organization as well as the environmental impact of food production and industrial processes in modern societies. Focusing on the signals--among them complaints--and how they are amplified, distorted, and damped draws our attention away from the technical details of ecological consequences of actions, individual decisions, class struggle, and theoretical considerations of power and force, to the social and political forms of policy making and implementation.

\section{The policy making process}

In the United States, as well as other nation-states, policy is formed in a complex interaction among legislative, judicial, and administrative processes (Clunies-Ross, et al. 1992; Durrenberger 1992; Pálsson 1991; Thu 1992). Each sector processes signals and makes authoritative decisions, some of which are contrary to or inconsistent with other decisions. In each sphere, science is a central dimension of policy formation. Expert witnesses testify in court proceedings on the scientific status of various practices and statements; legislators use the guidance of experts; and administrators are enjoined by law to adhere to scientific findings in formulating and enforcing regulations. Because the 
rhetoric of scientific analysis is highly valued (Miller 1987, Durrenberger 1992), signals that achieve scientific status are highly amplified.

State and United States legislators represent what they see to be the interests of their constituents in a process that is recognized as intensely political. Given conflicting interests among their constituents, they must make some judgment about which interests to favor in their attempts to shape legislation. This process amplifies, damps, and distorts the signals of interested parties. Individuals with common interests can band together into special interest groups to advance their interests to represent their points of view disproportionately, to amplify their signals in the system. An even more effective means is to organize as an interest group that does not appear to be representing an interest, but neutral scientific knowledge.

At county, municipal, state and federal levels the creation of administrative procedures to translate law into practice through regulations and rules that people can follow in everyday activity are similar. The administrative process does not represent interests in the same way as legislatures do, but is conceived of as a technical process to translate policy principles into practical guides for action. The legislature gives administrators something to regulate. Administrators call on experts, scientists and technicians, to define the issues and propose regulatory measures. The regulations are formulated in a technical, rather than an explicitly political context. In the United States, after the regulations are formulated, then the affected public are invited to comment directly on the issue, to represent their own interests to the policy makers. Often, there are cultural barriers to people speaking and others to their being heard that render the hearing process an ineffective channel for them to communicate their concerns, one that damps or distorts the signals they would like to send rather than amplifying them (Meltzoff 1989, Durrenberger 1992).

Proposed regulations are usually defined in terms of the best available scientific data. Thus control of scientific production and the definition of its questions and terms becomes an important political tool, even if the technicians involved do not see themselves as politically interested or active. If interest groups can masquerade as providers of technical information or control the process, they can amplify their messages and gain a large measure of influence. Sometimes, the community of technicians shares cultural constructs, paradigms, to use Kuhn's term (1962), which shape the formation or implementation of policy in ways that its originators never imagined and thus distorts their signals (Thu 1992).

The third source of law is the courts, which function to insure that proper procedure is followed, for instance adherence to scientific knowledge in administrative processes; and to interpret such matters as areas of jurisdiction, what branches of government have what powers. In each of the three processes, the rhetoric of scientific analysis is highly valued (Durrenberger 1992). The ideal of a neutral technocratic scientifically governed policy is obviated by the fact that different competing groups benefit differentially by policy decisions as well as by the many sources of signal distortion including differential muting and amplification in the process.

\section{Swine production and its discontents}

When we began investigating the industrialization of swine production in Iowa we heard about North Carolina from all quarters. North Carolina was the model for Iowa to follow. In 1993, there seemed to be no negative consequences and many positive ones 
including job creation, increased rural tax bases, adding value to corn locally, and keeping Iowa in the forefront of U.S. pork production. By 1994, industrial swine production systems in North Carolina had catapulted that state from its 7th place ranking in the U.S. in 1983 to 2nd place, behind Iowa.

North Carolina producers lead in two commonly used measures of efficiency of swine production--number of pigs produced per sow and feed to meat conversion ratio. Because they are moving up fast on the national charts and their operations are profitable even after paying 50 cents a bushel to transport corn from the middlewest, North Carolina represents a model of efficiency some agricultural industry leaders argue swine producers in Iowa should imitate.

As North Carolina style operations began to appear in rural Iowa, however, researchers at the Institute for Agricultural Medicine and Occupational Health at the University of Iowa began receiving calls asking for information about air and water quality. In the summer of 1993 we traveled through the swine producing area of North Carolina to talk to over a hundred rural residents to learn about their experience with such facilities. Two lessons were clear: more swine means more waste products and concentrated swine means concentrated waste products. Many swine producers had constructed single lagoons from which they spread effluent by means of rotating irrigation sprayers. The problem we heard most about was odor--how the appalling smell disturbs people and imprisons them in their homes. People complained that their property values had dropped precipitously and took us to smaller and larger watercourses to see runoff from industrial scale hog operations and processing plants.

As rural residents experienced discomfort in their own homes, they began to seek redress from agencies of local, county and state governments. They began to consider nuisance suits against the neighboring swine producers and consult with lawyers, often to discover only later that the lawyers represented the swine producing interests. Rural people began to organize, gather information, and make connections with other organizations and individuals. Their feelings of anger grew with the frustration they felt when they sought recourse and failed at every turn.

They faced the direct harassment of threatening telephone calls and letters as well as being followed when they drove their cars. They felt equally intensely the intimidation of threats to fire them or their relatives from local, county, and state positions if they attended meetings or participated in the growing opposition. Through such blatant harassment and intimidation, signals of discontent in North Carolina are systematically damped rather than amplified. Some people began to feel they had no place to turn, that all courses were closed to them.

The first notice residents may have of an intensive swine facility being planned for their area is often the preparation of the site for construction. North Carolina classifies swine production as agricultural so producers of any scale are not required to conduct environmental impact studies or hold public hearings. This and other legislation that favors large scale swine producers was promoted in the North Carolina legislature by Wendell Murphy, founder of Murphy Farms Inc., based in Rose Hill, North Carolina, which is the largest swine producer in the U.S., and the largest swine contractor in Iowa. This is a blatant example of the amplification of a signal for self-interest in a legislature.

Murphy's service in the legislature was terminated when he no longer sought election because of North Carolina Bureau of Investigation examinations of possible illegal financial dealings, but while he was a senator he played a pivotal role in engineering legislation to assist his company. Murphy also serves on the board of regents of North 
Carolina's agricultural university, North Carolina State University (Cecelski 1992; Kerr 1992a, 1992b). This is an equally blatant example of trying to achieve scientific status to amplify a signal in the legal system. People spoke with contempt of North Carolina State University's pronouncements on any issue, but especially any concerning swine production, which they felt to be an extension of Murphy's self-interest. They recounted instances of researchers and scientists from North Carolina State University addressing rural audiences to assure them that odor from industrial swine facilities was not a problem. As some put it, to tell them, "that hog shit don't stink."

Many people we talked to indicated that Murphy's place in the system was emblematic of a wider problem. From North Carolinians familiar with that state's legal and political system, we heard that pivotal positions were simply traded among a group of politicians, agribusiness owners, attorneys, and state employees. Some had been recruited from the ranks of the environmental movement. Rural residents expressed frustration and anger at the lack of respect for their concerns they encountered when they sought redress. As they have sought further for redress, and met further barriers, their frustration and anger has grown into a groundswell of organized opposition. Their signals had no way into the system--they were blocked at every turn.

\section{History}

An adequate understanding of the industrialization of swine production must ask why the explosive growth of has occurred in North Carolina, and why has it happened in the past few years. The extension economists Hurt (Purdue University) and Zering (North Carolina State University) (1993) suggest that the major impetus has come from packers.

Because they wanted to control the production of an additional 100,000 sows for their packing facilities in Virginia, Smithfield Foods had been trying since the mid 1980's to generate more pork production in Virginia. Environmental regulations and local concerns in Virginia caused them to look increasingly to North Carolina where they had developed relationships with several hog producers, such as Wendell Murphy. These relationships led Smithfield to locate a new processing plant in North Carolina.

While technological changes are necessary for industrial swine production, they do not explain it. It is the demand from the processing sector and the ability to ensure a steady supply of raw materials that drives the process. These relationships became formalized in North Carolina when Wendell Murphy was given a place on the board of Smithfield Foods. In effect, the processor and the swine suppliers act as a single integrated operation.

To simplify a complex process, processors want a more dependable, uniform, and predictable supply of pork. They would like to produce their own pork just as fish processors would like to own their own fishing boats (Durrenberger 1994). But if state laws or liabilities militate against such a solution, as in Virginia, processors form alliances with producers to encourage industrial scale production in other areas where there is less resistance. It is this process, not individual decisions of farmers, that provides the uses for the technology of intensive swine production. Meanwhile, those with interests in largescale swine production foster the development of relevant technologies through the agricultural universities and strive to attain scientific status for reasons to transform agricultural practices and thus selectively amplify signals that favor industrialization by giving them scientific status.

Some numbers help to visualize the signal amplification of pork producers. Publicly available records indicate that persons in North Carolina's state government placed a total 
of 4,659 telephone calls to Murphy Farms and its personnel in the two years between September, 1992 and August, 1994. Supposing a working year has 50 weeks of 5 days each, these two years would be a total of 500 working days. The average is 9.3 calls per day from North Carolina's state government to Murphy Farms, or an average of 1.16 call per working hour. The governor's office made 91 of the calls, an average of nearly one (.91) call per week. During the same time there were 206 calls from legislators, an average of.5 calls per hour, or one call per two working hours of these two years.

The North Carolina Pork Producers Association Political Action Committee's report of receipts and disbursements filed on April 17, 1994 reveals that for the Primary Election of March 3, 1994 the Committee contributed to 122 candidates--12 for the U.S. House of Representatives; 31 for the North Carolina Senate; 75 for the North Carolina House of Representatives; and 4 for county commissioners.

Robert Morgan, a North Carolina attorney and ex U.S. Senator, North Carolina Senator, and former Chief of the North Carolina Bureau of Investigation has documented (1994) some activities of Wendell Murphy on behalf of the swine industry when he was in the North Carolina Senate. Murphy sought to amend North Carolina zoning laws to designate swine production as farming so it could not be controlled by local zoning. According to Morgan (1994), counties are not willing to undertake the costs of court battles that the industry has promised if they attempt to zone. Murphy chairs a committee to endow scholarships for the Commissioner of Agriculture, and as Morgan (1994:8) puts it, "his influence with the legislature still lingers from his days as a member of the body and from his fund raising activities."

The evidence Morgan develops along with the telephone records and records of the contributions of the Pork Producers Association's Political Action Committee suggest that those who perceive strong connections between industrial swine production interests and state government at all levels in North Carolina are correct.

As larger operations proliferate, their neighbors begin to perceive negative consequences and start to organize and object. The objections are powerless until they are translated into policy that curbs the process, as they did in Virginia. Sometimes, court battles can increase the costs of large scale swine production to the point that it is not profitable, but such protracted battles are expensive and extremely costly in terms of social relations within the communities that undertake them (Delind forthcoming).

If we abstract away everything but the channels of communication and the nodes they connect, we can see a scheme in which processors communicate to producers and producers communicate to providers of technology and policy makers. Meanwhile, rural citizens communicate to policy makers to affect policy in their interests. The agricultural universities amplify the signals of processors and producers by providing scientific status for them, while they damp signals from citizens who object by labeling them antiprogressive and emotional. Legislative and administrative processes further disproportionately amplify signals that favor industrialization and damp objections. This process is not unique to North Carolina.

\section{Amplification, distortion, and damping of signals in Iowa}

To advise him on issues regarding livestock, the Governor of Iowa formed the State Livestock Industry Task Force and the Job Creation in Animal Agriculture Advisory Committee. They include strong representation from major agribusinesses in the state which have vested interests in representing technical research results for state policy 
makers. For example, a 1989 report prepared by these two groups, concluded that: "Methods need to be developed that will foster expansion of a livestock industry that is economically and environmentally sustainable" (Iowa State University and the Iowa Business Council 1989:114). However, data on hog production from Iowa State University's Swine Enterprise Record Program presented earlier in the same report contradict the efficacy of promoting a general expansionist policy for hog farmers: "At first, one might assume that the high-profit farms are larger and therefore have higher profit levels... The bottom line is that revenues were not higher because operations were larger" (ibid:77). This finding is consistent with other studies that have found that there are no efficiency advantages to large scale swine production (Ikerd 1994; Thornton 1993).

Despite mixed signals from this joint report, the Iowa Department of Economic Development (IDED) cited it as a principle reason, a scientific justification, for approving a \$230,000 forgivable loan application for a North Carolina company to build a facility in Iowa to produce equipment for intensive hog production. In their application, the company said it would provide the technology to shift the pork industry from mostly small operations to large-scale facilities. The IDED stated that the Iowa Business Council and Iowa State University study supported the need to reshape the hog industry along the lines proposed by the North Carolina firm. In fact, the report cited by IDED can be used to support just the opposite conclusion, that there is no inherent economic benefit for hog farmers in expanding their operations.

This is one example of the selective distortion of a signal and amplification of the "industrial" signal in the formation of public policy with important long-term consequences for Iowa's agriculture and food production in the United States. The loan was granted in spite of widespread opposition from Iowa firms that already produce the same kinds of apparatus. Other groups in the system espousing the importance of family based independent farmers manipulate representations to support their interests in the system as well. For instance, Prairie Fire Rural Action, a nonprofit organization whose self-proclaimed mission is to "revitalize family farm agriculture" in Iowa, is one of the leading opponents of industrialized hog production in the state. In lamenting the demise of the family hog farm, Prairie Fire provides another representation of information from yet another node in the system (Prairie Fire Rural Action 1993:3):

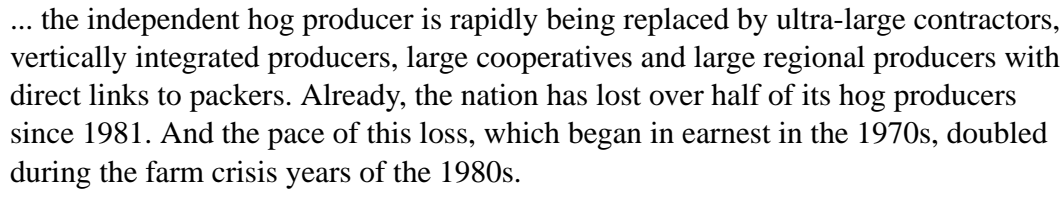
vertically integrated producers, large cooperatives and large regional producers with direct links to packers. Already, the nation has lost over half of its hog producers since 1981. And the pace of this loss, which began in earnest in the 1970s, doubled during the farm crisis years of the 1980s.

In this opening salvo in its 1993 report against intensive hog production, Prairie Fire fails to mention data showing that in 1991 the number of hog farmers in Iowa actually increased from 34,000 to 35,000. This increase occurred in the midst of increasing numbers of large-scale intensive hog production units allegedly having a detrimental effect on small family farmers. The difference is that this distortion did not form a basis for any public policy.

One way to amplify signals in state systems is to gain scientific status for propositions that serve one's interests. One can do this by trying to influence research agendas--for instance at agricultural universities. That is the reason that it is important that Wendall Murphy serves on the board of regents for North Carolina State University. When Iowa's Department of Economic Development attended only to one line of evidence, giving it the 
imprimatur of scientific relevance, it amplified one signal and damped equally legitimate alternative findings.

Interest groups amplify signals by repeating them, developing fora for their repetition, and compiling evidence in the service of their positions. A statement to a friend is a weak signal; a letter to the editor reaches a larger audience; a newspaper story is widely read; a television story even more widely seen. A group becomes a social phenomenon, thus news, and gains attention and power. The press is often known as the fourth branch of the U.S. governmental structure. Parties who wish to influence policy organize as groups to amplify their messages.

At least some small scale swine producers in Iowa think that the Iowa Pork Producers Association represents the interests of large scale producers disproportionately. The association's position is that large scale production is inevitable, so Iowa pork producers should increase the scale and efficiency of production, which the association can best promote by educational programs. Some small scale producers argue that they are not lacking knowledge, but for various reasons--because they do not want to specialize in pork, because they do not want to risk a large debt--they do not wish to increase the scale of their operations. In Missouri and Kansas, small producers have formed separate organizations to represent their interests. In representing large scale swine production as the only viable alternative, the Iowa Pork Producers Association is amplifying one signal and damping another.

The association can further amplify this signal by gaining quasi-official and at least quasi-scientific status for the details of their program through the operation of such official agencies as the Governor's Livestock Revitalization Task Force. The chair of the task force was the David Topel, Dean of the College of Agriculture of Iowa State University. Among its 21 members were 4 Iowa legislators, 19\%; 8 representatives of livestock associations, 38\%; two bankers, one representing the Chamber or Commerce, a representative of the Department of Natural Resources, the president of the Governor's Livestock Revitalization Task Force, charged to increase Iowa's livestock production and remove any barriers to adding $1 \%$ of the national market share; a representative of the Iowa Farm Bureau Federation, a representative of the Leopold Center for Sustainable Agriculture at Iowa State University; a representative of the Izaak Walton League, an environmental group; and one representative of an organization that had grown up to protest large scale swine production, the Organization for the Protection of the Environment.

After public hearings around the state, the representative of the Pork Producers Association presented a plan to the committee which was approved after some token discussion and after it voted down the alternatives presented by the two representatives of environmental groups. The association's plan was issued as the commission report only slightly modified in December of 1994. This committee, with all of the dressings of democratic policy making, acted to amplify one signal and damp another.

In an attempt to develop alternative viewpoints, 25 individuals formed a Citizens Task Force on Livestock and issued an alternative set of recommendations in October of 1994. Prairie Fire Rural Action, Organization to Protect the Environment, the Iowa Sierra Club, The Iowa Citizen Action Network, the Iowa Farm Unity Coalition, and three religious groups endorsed the report, though it had no official standing, affected no policy, and thus did not effectively amplify any signal. Dismissal of any such proposals or findings as unscientific, emotional, and "unrealistic" by the Dean of the College of Agriculture of Iowa State University and governor serve to damp such signals. 
A well known way to amplify a signal is via political contributions. In 1994 one of the chief industrial producers of swine in Iowa was among the top ten financial contributors to Governor Terry Branstad's reelection campaign. As part of the Governor's effort to shape policy, he bypassed the State Secretary of Agriculture, a democrat, to form his Livestock Revitalization Task Force and approved a three million dollar agricultural research fund for Iowa State University's College of Agriculture, home of David Topel, the Dean and leader of the Task Force (DesMoines Register March 1, 1993. The head of the Task Force to investigate swine industry issues was beholden to the Governor for a research budget (Thu 1995). The Dean, the Governor, and the chief industrial producer are thus intimately linked to all amplify the same signal--industrialize swine production. Kendall Thu (1995:15) concluded that "... rural residents throughout Iowa, have little chance of getting their concerns redressed through political channels influenced by the Governor and powerful affiliates at the state's land grant institution that provide the imprimatur of science for the expansion of industrial hog production facilities."

\section{Conclusions}

As we write, these issues are being debated in the Iowa legislature. In February 1994 more than 90 individuals testified at a public hearing requesting the legislature to enact more stringent regulations than the Governor's committee recommended. Whatever the legislature does, the same issues will be debated in counties and in courts for the foreseeable future as interested parties and groups try to make use of other policy making alternatives to favor their interests.

In these examples we have not completely described the complexities of policy formation with respect to large scale swine production in Iowa. We have mentioned some of the components and shown how some signals become amplified while others become muted or damped. We have shown the complicity of Iowa State University in the process of providing some messages with the status of "scientific" and how that seemingly neutral academic process amplifies some signals and dampens others which are equally defensible on scientific grounds.

We suggest that these are the processes that deserve further attention in attempting to understand the relationships between modern agriculture and environmental quality. Because the environmental consequences will depend on policy, the process of policy formation is an important part of modern state organized environmental systems. We have suggested that complaints are an integral part of the environmental system, and that people are facing similar problems and issues wherever there are too many pigs--New Guinea, North Carolina, and everywhere in between. In New Guinea the links between the hogs and the people are more direct and complaints act as a brake on ecological damage. In Iowa and North Carolina the links are more remote and rural residents who are affected cannot automatically affect the remedies.

It is in the best interests of everyone to listen to this source of information to correct systemic errors before they become pathological. However, this source of information is often damped in the process of policy formation while the signals from the interests that promote large scale swine production are amplified. It is in part through this differential amplification of signals that class interests are served in state societies. 


\section{REFERENCES CITED}

Barlett, Peggy F.

1989. Industrial Agriculture. In Economic Anthropology, pp. 253-291, S. Plattner, ed. Stanford: Stanford University Press.

Bennett, John W.

1982. Of Time and Enterprise: North American Family Farm Management in a Context of Resource Marginality. Minneapolis: University of Minnesota Press.

Cecelski, David and Mary Lee Kerr 1992. Hog Wild. Southern Exposure 20 (3):9-15.

Clunies-Ross, Tracey and Nicholas Hildyard 1992. The Politics of Industrial Agriculture. The Ecologist 22(2):65-71.

Cochrane, W. W.

1979. The Development of American Agriculture. Minneapolis: University of Minnesota PRess.

Delind, Laura

forthcoming. The State, Hog Hotels, and the "Right to Farm:" A Curious Relationship. Agriculture and Human Values.

Durrenberger, E. Paul

1986. The Cultural-Historical Background to the Middlewestern Farm Crisis. Culture and Agriculture 28:15-17.

1992. It's All Politics: South Alabama's Seafood Industry. Urbana: University of Illinois Press.

1994. Shrimpers, Processors, and Common Property in Mississippi. Human Organization. 53 (1):74-82.

Flannery, Kent

1972. The Cultural Evolution of Civilizations. Annual Review of Ecology and Systematics 3:399-426.

Fried, Morton

1967. The Evolution of Political Society: An Essay in Political Anthropology. New York: Random House.

Gladwin, Christy

1980. A Theory of Real-Life Choice: Applications to Agricultural Decisions. IN Agricultural Decision Making. P.F. Barlett, editor. pp. 450-85. NEw York: Academic Press

Gladwin, C. and J. Butler

1984. Is Gardening an Adaptive Strategy for Florida Family Farmers? Human Organization 43(3):208-216.

Gladwin, C. and M. Murtaugh

1980. The Attentive-Preattentive Distinction in Agricultural Decision Making. IN Agricultural Decision Making. P.F. Barlett, editor. pp. 115-136. New York: Academic Press.

Gladwin, C. and K. Truman, editors.

1989. Food and Farm: Current Debates and policies. Lanham: University Press of America. 
Gladwin, C. and C. Zulaluf

1989. The Case for the Disappearing Mid-Size Farm. IN Food and Farm: Current Debates and Policies. C. Gladwin and K. Truman, editors. Lanham: University Press of America.

Goldschmidt, Walter

1978. As You Sow: Three Studies in the Social Consequences of Agribusiness. Montclair, N.J.: Allanheld, Osmun and Company.

Hurt, Chris and Kelly Zering

1993. North Carolina Hog Industry Grows: Why There? Why Now? Iowa Farm Bureau Spokesman, August 28, 1993:4.

Ikerd, John E.

1994. The Economic Impacts of Increased Contract Swine Production in Missouri. Unpublished Manuscript. University of Missouri Sustainable Agriculture Systems Program.

Johnson, G.A.

1978. Information Sources and the Development of Decision-Making Organizations. IN Social Archaeology: Beyond Subsistence and Dating. 1C. Redman, editor. Pp. 87112. New York. Academic Press.

1982 Organization Structure and Scalar Stress. IN Theory and Explanation in Archaeology. C. Renfrew, M. Rowlands, and B.A. Seagraves, editors. New York: Academic Press.

Kerr, Mary Lee

1992a. Corporate Farms Stink. Southern Exposure 20 (3):15.

1992b. Murphy's Law. Southern Exposure 20 (3):11.

Kuhn, Thomas

1962. The Structure of Scientific Revolutions. Chicago: University of Chicago Press.

Kus, S.

1981. The Context of Complexity. IN Archaeological Approaches to the Study of Complexity. S.E. van der Leeuw, editor. pp. 198-227. Amsterdam: Universiteit van Amsterdam.

Labao, Lind M., Michael D. Schulman, and Louis E. Swanson

1993. Still Going: Recent Debates on the Goldschmidt Hypothesis. Rural Sociology $58: 277-288$.

Mathews, H.F.

1987. Predicting Decision Outcomes: Have We Put the Cart Before the Horse in Anthropological studies of Decision Making? Human Organization 46:54-61.

Meltzoff, Sarah K.

1989. Politics of Conservation in the Florida Keys. IN E. Paul Durrenberger, Lee Maril, and J. Thomas, editors., Marine Resource Utilization. Mobile: MississippiAlabama Sea Grant Consortium MASGP-88-039. pp. 125-132.;44:183-184.

Miller, Marc L.

1987. Regional Fishery Management Councils and the Display of Scientific Authority. Coastal Management 15:309-318.

Morgan, Robert

1994. Policy, Law and Industrial Hog Production in North Carolina. Paper presented at the 1994 American Anthropological Association meeting. 
Pálsson, Gísli

1991. Coastal Economies, Cultural Accounts: Cultural Ecology and Icelandic Discourse. Manchester: Manchester University.

Reynolds, R.G.

1984. A Computational Model of Hierarchical Decision Systems. Journal of Anthropological Archaeology 3:159-189.

Scott, James

1985. Weapons of the Weak. New Haven: Yale University Press.

1991. Domination and the Arts of Resistance. New Haven: Yale University Press.

Thornton, Kieth

1993. Where will European Housing Trends Lead? Pork 93: The Business Monthly for Pork Producers. August, 1993:38-40.

Thu, Kendall M.

1992. Norwegian Farm Strategies and the State: Implications for a Global Pattern. PhD Dissertation, The University of Iowa.

1995. Piggeries and Politics: Rural Development and Iowa's Multibillion Dollar Swine Industry. Paper presented at the meeting of the Society for Applied Anthropology.

n.s. What's a "Year's Work" Worth?: The Influence of the State on Cultural COnstructs of Farming and Farm Conditions in Norway. Unpublished ms.

Thu, Kendall and E. Paul Durrenberger

1994. North Carolina's Hog Industry: The Rest of the Story. Culture and Agriculture 49:20-231

Van der Leeuw, S.E.

1981. Information Flows, Flow Structures and Explanation of Change in Human Institutions. IN Archaeological Approaches to the Study of Human Complexity. S.E. Van der Leeuw, editor. pp.. 230-312. Amsterdam: Universiteit van Amsterdam.

Williams, Raymond

1977. Marxism and Literature. Oxford: Oxford University Press.

Wright, H.T.

1986. The Evolution of Civilizations. IN American Archaeology Past and Future. D.J. Meltzer et al., editors. pp.. 323-365. Washington, D.C.:Smithsonian Institution Press.

\section{Abstract:}

This paper explores characteristics of the "alternative medicine" or ecological paradigm and some of its implications for health po9licies. This paradigm suggests that many degenerative diseases (including cancer) are "caused" or accellerated by the building of industrial toxins and that effective public policies should encourage wholistic preventative changes, including in food and water systems, rather than primarily addressing symptoms.

Key Words: disease, health, industrialization, pollution, ecology, alternative medicine, ecological pressure, health policy. 


\section{Résumé}

Cet article examine des caractéristiques du paradigme écologique ou "de médecine alternative" et certains d'entre ses implications pour des politiques de santé. Ce paradigme suggère que beaucoup des maladies dégénératives (à savoir cancer) soient "provoquées" ou accéllérées par la fabrication des toxines industrielles et que des politiques efficaces publiques devraient encourager des changements préventifs à grande échelles, à savoir changements dans les systèmes d'alimentation et d'eau, plutôt que s'adresser principalement aux symptômes.

Les mots clé: la maladie, la santé, industrialisation, pollution, écologie, la médecine alternative, la pression écologique, la politique de santé.

\section{Resumen}

Este artículo explora los caractersticas de "medicina alternativa" o el paradigma ecolgico y algunas de las implicaciones que tiene para políticas de salud. Este paradigma sugiere que muchas de las enfermedades degenerativas (incluyendo cncer) son "causadas" e incrementadas por el crecimiento de toxinas industriales y que políticas publicas eficaces en vez de tratar los síntamos deben promover cambios holísticos preventivos, incluyendo cambios en los sistemas alimenticios y hidrolgicos.

Palabras claves: enfermedad, salud, industrializacin, contaminacin, ecologa, medicina alternativa, presin ecolgica, políticas de salud. 
E. Paul Durrenberger and Kendall M. Thu

\section{This Page Left Blank}

